\title{
The academic study of Canadian Jewish preachers
}

\author{
MARC SAPERSTEIN \\ Leo Baeck College, London, UK \\ E-mail: Marc.Saperstein@lbc.ac.uk
}

The conference entitled "“A Skilled Tongue': Sermon and Society in the Canadian Jewish Experience," held in Montreal on October 24-25, 2004, was to my knowledge the first conference devoted entirely to the academic study of Jewish Preaching. Modest in comparison with a later conference of the Israel Historical Society in Jerusalem on July 16-17, 2007, "Doresh Tov le-Amo': Ha-Darshan, ha-Derashah ve-Sifrut ha-Derush ba-Tarbut haYehudit", with papers covering all periods and many countries, the Montreal meeting was a pioneering event. This was thanks in no small part to its organizers, Ira Robinson and Richard Menkis, who labored greatly to ensure the publication of the essays in this joint issue of Jewish History and Canadian Jewish Studies/Études juives canadiennes. ${ }^{1}$

The studies published here include one about a nineteenth-century immigrant from London's Orthodox Sephardic community, three concerning Orthodox immigrants from Eastern Europe, flourishing from late nineteenth century through first half of twentieth, and one discussing a Conservative immigrant to Canada from the United States during the third quarter of twentieth century. All of these rabbis served congregations in Toronto or Montreal. There is no independent study of a Reform rabbi; a paper presented to the conference on the subject of interfaith dialogue in the sermons of Harry Joshua Stern, who served as Rabbi of Temple Emanu-El of Montreal for some forty-five years and was known especially for his work in this field, regrettably was not elaborated for inclusion in the present collection. ${ }^{2}$

Reform synagogues were always a minority in Canada: only 3 out of 152 in 1935, and 7 out of 206 in $1960 .{ }^{3}$ Nevertheless, they included some of the largest and wealthiest congregations in Toronto and Montreal, and many of their rabbis were outspoken and influential. As in the United States, Reform Rabbis were prominent spokesmen from the pulpit for issues of social justice that transcended the needs and interests of the Jewish community itself. ${ }^{4}$ But the sermons by rabbis of Holy Blossom Temple of Toronto, which from 1920 had a series of outstanding preachers, especially Maurice N. Eisendrath (1930-1943, see below), Abraham L. Feinberg (1943-1961, voted in a 1951 national poll to be one of Canada's seven greatest preachers), ${ }^{5} \mathrm{~W}$. Gunther 
Plaut (1961-1977, perhaps best known as the editor of The Torah: A Modern Commentary), ${ }^{6}$ and Dow Marmur (1983-2000) deserve full attention in their own right.

\section{Language}

The issue of language is one of the most important raised here. In general, Jewish sermons were delivered in the vernacular spoken by the congregation of listeners. However, the disruptions of emigration created circumstances in which there were two vernaculars, one spoken by the emigrant Jews, the other by the host population. In some instances, this linguistic discrepancy continued for centuries: Judeo-German (Yiddish) spoken by Jews in Poland, Judeo-Spanish spoken by Jews in the Ottoman Empire. In others, the emigrant population maintained its distinctive native language for several generations (the Portuguese communities in Amsterdam and London), and in some the original language was abandoned by the first generation to be born in the new country. The language of the sermons is a marker of cultural adaptation to the new environment.

Richard Menkis addresses this issue at the beginning of his essay on Abraham de Sola, who served the Portuguese congregation of Montreal in the third quarter of the nineteenth century. Following directives from the congregation's Board and the recently established practice of the mother congregation in London, he preached in English. This practice was more contested in Ashkenazi congregations. Jacob Gordon in Toronto preached in Yiddish, and was opposed to using English in the pulpit; as noted by Steven Lapidus, he insisted that it was better to leave a synagogue in the middle of a worship service than to listen to a sermon in English. Hirsch Cohen, known as "the Maggid of Montreal," was more interested in content than in language and supported sermons in the vernacular, though he himself preached in Yiddish. It is perhaps worth noting that the current Sephardic Chief Rabbi of Quebec, Rabbi David Sabbah, educated in Morocco and France, writes and preaches in the French language-which probably would have astonished his predecessor Abraham de Sola.

\section{Preservation of texts}

That both Gordon and Yudel Rosenberg chose to publish their sermons in Hebrew introduces another theme: the way the sermon texts were preserved, and the complex relationship between these texts and the sermon as actually delivered. All of the studies published here are based on written texts, which 
may be our best evidence for the actual sermon delivered in a specific setting before a group of listeners, but the texts are not identical with the sermon itself. And the texts themselves are altered, revised, translated, expanded, condensed, or otherwise mediated by authors and editors.

Obviously a text re-written by the preacher in Hebrew primarily as a resource for other preachers (Yudel Rosenberg) may differ significantly in its rhetorical repertoire from what the listeners heard in a Yiddish original. ${ }^{7}$ Similarly, a text as reported in summary with a few quotations in general newspapers, Jewish periodicals (de Sola), or the Yiddish press (Cohen), while often based on full original texts, will generally recount what someone other than the preacher considered to be newsworthy. Occasionally, a newspaper will publish a full text of the sermon as written by the preacher. This represents a significant expansion of the audience for the sermon beyond the original listeners for whom it was intended.

The same is true for the most common way in which sermons have become accessible to a wider readership years after it was originally delivered: incorporation into a collection of the preacher's sermons (Yudel Rosenberg, Stuart E. Rosenberg). This obviously reflects the author's selection of what he considered worthy of putting out in the public domain, and usually it will involve some degree of re-writing to polish a style intended for oral delivery. A fundamental choice to be made by a preacher selecting texts delivered over many years, or even decades, for a single book, is whether to focus on the "timeless" sermon, that could have been given ten years earlier or later, or the "topical" sermon responding to specific issues and events of the moment, that could never be repeated in exactly the same form.

Especially prolific in his publication of collected texts was Harry Joshua Stern of Montreal, with five books, four of which are identified in the subtitle as "A Collection of Addresses". 8 This raises a question of genre. Some of these "addresses" were delivered at gatherings outside the synagogue, but others were clearly spoken at synagogue services, and it is unclear why he did not classify them as "sermons"-perhaps because they are usually not linked with the parasha or a central exegetical issue. Many speak to current topical issues (examples below); while he did not record the dates of delivery, more than a few are datable from internal evidence.

Eisendrath instituted the "Holy Blossom Pulpit" series in 1931. This was a practice familiar in the United States from such series as "Our Pulpit" of Temple Keneseth Israel of Philadelphia (Joseph Krauskopf), "Reform Pulpit" of Rodef Shalom Congregation in Pittsburgh (J. Leonard Levy), "Free Synagogue Pulpit" of the Free Synagogue in New York (Stephen S. Wise). These in turn were modeled after similar series in great metropolitan churches in England (Metropolitan Tabernacle Pulpit, C. H. Spurgeon) and the United States (Messiah Pulpit and Unity Pulpit, Boston, Minot J. Savage). Most 
of these Jewish series were publications of Sunday morning sermons or addresses that formed the central part of a weekday morning worship service; the text of the address, either provided by the preacher or stenographically transcribed during delivery, was then printed in pamphlet form for distribution or sale the following Sunday (The Holy Blossom Pulpit sermons sold for 10 cents). In some cases, all of the pamphlets from a single year would be published together in book form. Twelve volumes of the Holy Blossom Pulpit were published between 1930 and 1943, a rich source for high level religious oratory on contemporary issues, often rooted in biblical passages, though certainly far removed from traditional Jewish preaching.

\section{Rebuke}

In addition to topics relating to the external characteristics of the sermon texts I will mention just a few of themes obvious in the content of the material surveyed. The first is the rhetoric and substance of rebuke, when the preacher did not set out primarily to educate but to criticize what he considers significant shortcomings in the behavior of the general society, the broader Jewish community, or his own congregation of listeners. Needless to say, the closer the object of rebuke is to the people in the pews, the more deft will need to be preacher's technique of expressing criticism in a manner that will gain assent and not alienate listeners counter-productively. From the historian's perspective, the central challenge is to differentiate between conventional topoi that can be documented in every generation, and topics that reflect lines of tension in his own specific context. ${ }^{9}$

We see Abraham de Sola already drawing a fine line between an isolationist repudiation of all social and intellectual contacts with Gentile society and an openness leading toward intermarriage, resulting in the loss of children to the Jewish faith. His harsh words on this topic, he insists, necessitated by "recent melancholy events"- apparently alluding to intermarriage within his own community-will be "in unison with those of Moses and the Prophetsas to the unpardonableness of an Israelite abandoning his own people for the daughters of the land". Here he finesses of course the issue of Moses' own marriage to a Midianite women.

Two generations later, Yudel Rosenberg considered rebuke to be one of the most significant tasks of the preacher: "to bring the children of Israel to their highest level through their sermons of moral reproof" (tokhehat musar). For Rosenberg, the Judaism he represented was under siege by powerful forces, including the militant secularists in the Jewish community itself. Rosenberg situates his sustained polemic against secular education for Jewish children in the context of a highly contentious issue of his time. He apparently saw 
no value in the broader culture of his environment, associating it with the foreign culture of ancient Egypt which may have been seductively appealing to some but was inimical to Torah Judaism.

For Hirsch Cohen, the "Montreal Maggid", the preaching of rebuke was one of the central functions of the sermon. Unlike their Christian counterparts, very few Jewish preachers historically made a claim to direct divine inspiration, or that they were articulating a message that came directly from God. ${ }^{10}$ But Cohen saw rabbis as the heirs to the prophets, not as a group who substituted a new mode of leadership for one that was deemed no longer in operation, but as the figures who were at present responsible for fulfilling a very similar function. Cohen, as Stephen Lapidus informs us, referred to himself rather audaciously and idiosyncratically with the title Navi-Rav, "Prophet-Rabbi", and articulates his reticence in criticizing charitable donations from well-known businessmen by saying that "every prophet knows the pain of suppressing prophecy".

\section{Reform Judaism}

The engagement of preachers with the Reform movement is in evidence from the middle of the nineteenth century, long before the movement had begun to make significant inroads in Canada. As Richard Menkis shows, Abraham de Sola condemned the readiness of American Reform leaders such as Isaac Mayer Wise to jettison the practices of a venerable tradition, including Shabbat, circumcision, and the Hebrew liturgy, because they are no longer consistent with the "enlightened" spirit of the modern age. Though de Sola was not a reactionary, accepting the need for some accommodation to modernity, the polemical spirit continued throughout his preaching career.

Not surprisingly, immigrants from eastern Europe were even more appalled by the breaks from tradition justified and rationalized by the Reformers. Ira Robinson mentions this theme in the sermons (and other works) of Yudel Rosenberg in Montreal. Perhaps because Reform was late in establishing itself in Canada, and remained a minority movement, there does not seem to be the sustained polemic exemplified in the withering attack on British Liberal Judaism launched in a series of three sermons by Chief Rabbi Joseph $\mathrm{H}$. Hertz in late 1925 and early $1926 .^{11}$

\section{Zionism}

Attitudes toward Zionism, linking matters of theology and doctrine with events in the broader world political context, are not easily correlated with denominational lines. Yudel Rosenberg affirms the traditional anti-Zionism 
of orthodox quietism, finding roots in Zechariah's message to Zerubavel that the redemption of the Jewish people in the land of Israel cannot be achieved through human initiative and physical or military power. Hirsch Cohen, by contrast, though similarly uncompromising on his orthodox credentials was a strong supporter of the Zionist enterprise.

The same division can be seen among Reform Rabbis in the 1930s: Eisendrath of Toronto was vehemently opposed on classical universalistic grounds, ${ }^{12}$ while Stern of Montreal was an outspoken supporter of the Zionist enterprise. He frequently spoke from the pulpit of his visits to Palestine and the flourishing of a dynamic economy and culture there. His firm commitment led to considerable anguish over what appeared to be a clear change in the previously favorably British policy in the late 1930s, culminating in the infamous "White Paper", as can be seen in the following passage: "This is indeed an hour of distress for world Jewry. Our people are aroused by well-founded rumors that His Majesty's government contemplates a reversal of policy in Palestine which spells nullification of the Balfour Declaration. Should this be permitted to happen there will be an adding to the already overflowing cup of Israel's suffering."13 Further investigation of the position taken by Canadian rabbis regarding the policy of the British Government in the years immediately following the war, in comparison with their counterparts in England and the United States, would be illuminating.

Conservative Rabbi Stuart Rosenberg is characterized by Michael Brown as having "special passion for Israel, which he saw as an embodiment of Jewish values" and especially important for the identity of Canadian Jews (n. 72); in this respect, he was close to the position of the Reform Rabbi Harry Joshua Stern. Rosenberg was also actively engaged from the pulpit and through other media in the cause of Soviet Jewry before it became a cause with a broad base of Jewish support, despite being cautioned against speaking out publicly on a sensitive issue.

\section{War}

Menkis shows us that Abraham de Sola delivered sermons on occasions shared by Jews with their neighbors in the general society, such as the special days of prayer proclaimed by the Government in times of epidemic (typhus, cholera), and when the mother country was engaged in war (Crimea, Indian Mutiny). ${ }^{14}$ Such sermons in times of crisis constitute important evidence for the development of a sense of patriotic identification with the country of residence and solidarity with Christian fellow citizens praying simultaneously in their churches. Note, however, that as Menkis points out, near the end of his career, de Sola accused American Jews of a "want of patriotism"-referring 
not to the failure to feel sufficiently American, but rather to their lack of loyalty to the traditions of the Jewish people."

One would like to know- and someday we can hope for a discussion of this subject-what Canadian Rabbis were saying about the Great War following Canada's entrance, with other Dominions of the Empire, in August 1914, and when the full dimensions of the bloodbath began to become apparent. Was there ambivalence, as in England, about entering combat as an ally of Czarist Russia against Germany and Austria, whose treatment of Jews was so much more enlightened? Did Canadian Jewish leaders share with their American colleagues the view that Canada had no obvious role in a European conflict, or did the identification with Britain outweigh the identity as a nation of the New World?

And World War II? How prevalent were pacifist sentiments articulated by Canadian rabbis (as by some American and British rabbis) in the 1920s and 1930s, and how were they affected by the entrance of Canada into a new European war? Harry Joshua Stern of Montreal provides an example. His sermons from the mid-1930s do reveal a pacifist outlook: "Through heroic idealism we must stake all and refuse to lift sword against fellow-man. If we do this, we may yet save ourselves. Failing in this, we and our entire civilization are destined for annihilation." ${ }^{15}$ On Rosh Hashanah 1939, nine days after Canada's declaration of war on Germany, Stern agonizes over the reality that war has again broken out "at a time when on all sides (!) there is the universal and accepted recognition of the futility of war. In a war there is no victor. Everybody loses. Is not this the lesson derived from the last world war? American rabbis at this time almost universally understood the lesson of the last world war to be that the United States should not enter the European conflict. ${ }^{16}$ Stern, though unable to celebrate Canada's entry into the war, is also unwilling to criticize, as a pacifist, the decision of his country: "In the dark grave year, and perhaps years ahead, we Jews pledge our might and substance and manpower to the support of Britain and her Allies. Jews where they are free to choose will unhesitatingly enter in the service of these democratic governments." 17

We have some insight on the unique position of Canada in September 1941-unlike its neighbor to the south officially engaged in the war since the outset, yet unlike Great Britain suffering none of the immediate consequences-from a powerful sermon by Maurice N. Eisendrath. ${ }^{18}$ However, much more is still to be learned from published and unpublished texts about attitudes regarding the war (especially in the wake of Allied defeats), just as we may also look forward to information communicated from the pulpit about the worsening situation, the systematic destruction of European Jews, and the theological challenges posed by unprecedented contemporary events. 
The same goes for other areas of enquiry. Whether Canadian Jewish preaching, with all its diversity, is characterized by distinctive qualities that are not shared with the far larger corpus of material from the United States and England is a topic truly worthy of addressing, as investigation into the fertile fields of sermonic literature continues apace.

\section{Notes}

1. In between these two, there was another conference with a somewhat different format: "Two Homiletical Traditions," held at Bamberg in March 2007, with papers published in the volume Preaching in Judaism and Christianity: Encounters and Developments from, Biblical Times to Modernity, ed. Alexander Deeg, Walter Homolka, and Heinz Günther Schöttler Berlin: Walter de Bruyter, 2008.

2. Mirela Saim, "Preaching Bridge-Building in Montreal," unpublished conference paper.

3. Susan Landau Chark, "The Story of One Suburban Synagogue and Its Founding Rabbi" (on Abraham Bernard Leffell), pp. 3-4, citing Louis Rosenberg, "Two Centuries of Jewish Life in Canada," in Canadian Jewish Reference Book and Directory, ed. Elie Gottesman, (Montreal, QC: Central Rabbinical Seminary of Canada, 1965): 189. http://web2. concordia.ca/canadianjewishjournal/pdf/susan_landau_chark.pdf; viewed February 23, 2009.

4. See Gerald Tulchinsky, “Justice and Only Justice Thou Shalt Pursue': Considerations on the Social Voice of Canada's Reform Rabbis", in Religion and Public Life in Canada, ed. Marguerite Van Die (Toronto: University of Toronto Press, 2001), pp. 313-328. We look forward to the publication of Norma Joseph's study of another Reform Rabbi, "Elyse Goldstein: Outspoken Canadian Rabbi," which introduces the theme of women's voices and how they provided a new dimension of pulpit discourse.

5. Many of Feinberg's sermons delivered at Holy Blossom Temple are in the American Jewish Archives.

6. See the recently published One Voice: The Selected Sermons of W. Gunther Plaut, ed. by Jonathan V. Plaut (Toronto: Dundurn Press, 2007). Unfortunately, the edition leaves much to be desired, with no editorial effort made to identify even biblical and rabbinic quotations, let alone quotations from contemporary authors, or to explain references and allusions to contemporary issues. Cf. the review by Margaret Wenig, Journal of Reform Judaism 55:4 (Fall 2008): 98-103. Two archival collections of Plaut's papers, at the American Jewish Archives and York University, contain unpublished sermons. 
7. The content also may differ, with allusions to local contemporary issues and humorous remarks omitted, while discussion of exegetical or halakhic details may be expanded. On this dynamic, see Saperstein, Jewish Preaching 1200-1800 (New Haven: Yale University Press, 1989), pp. 20-24.

8. Harry Joshua Stern, Judaism in the War of Ideas: A Collection of Addresses (New York: Bloch, 1937); The Jewish Spirit Triumphant: A Collection of Addresses (New York: Bloch, 1944); Martyrdom and Miracle: A Collection of Addresses (New York: Bloch, 1950); Entrusted With Spiritual Leadership: A Collection of Addresses (New York: Bloch, 1961); One World or No World: A Collection of Sermons, Essays and Addresses (New York: Bloch, 1973).

9. On this theme, see Saperstein, Jewish Preaching 1200-1800, 57-61; idem, "Your Voice Like a Ram's Horn: Themes and Texts in Traditional Jewish Preaching" (Cincinnati: HUC Press, 1996), pp. 127-146.

10. For the rare exception, see, Saperstein, "Your Voice Like a Ram's Horn", pp. $8-9$.

11. Hertz, The New Paths: Whither Do They Lead? (London: Oxford University Press, 1926); cf. his attack on "the Reformed Jewish Church of America" in an April 1914 sermon, idem, Sermons, Addresses and Studies 3 vols. (London: Soncino Press, 1938), 1:309-310.

12. See the diatribe from a Toronto 1934 sermon that he cited in Can Faith Survive? (New York: McGraw Hill 1964), pp. 48-49, describing his own sermon three decades later as "rash and angry words".

13. Stern: "Palestine and Great Britain", in The Jewish Spirit Triumphant, p. 116. Internal references show that this sermon was delivered after the Munich Pact of September 1938 dismembered Czechoslovakia, and before the Woodhead Palestine Partition Report of late October 1938, which led to the issuing of the White Paper of 1939. It was a time of civil uprising by the Arab population.

14. Menkis's characterization of de Sola's sermon on the Indian Mutiny should be compared with the sermon delivered by David Woolf Marks, minister of the British Reform West London Synagogue, on the Day of National Humiliation and Prayer the previous month; see Marc Saperstein, Jewish Preaching in Times of War, 1800-2001 (Oxford: Littman Library, 2008), pp. 125-141. Despite the differences of denominational affiliation, the sentiments about the Indian rebels and their ungratefulness for the benefits of British colonial rule are stunningly similar.

15. "Little World, What Now?" in Judaism in the War of Ideas, p. 116, dated by internal references. Also, "We are charged with being pacifists. What of it?" in idem, "How Shall the Jew Face the World?", ibid., p. 12, probably from autumn 1936. Cf. Eisendrath, who was President of the Toronto 
Chapter of the Fellowship of Reconciliation, articulating this position with characteristically robust rhetoric in a 1931 sermon: Can Faith Survive, pp. 70-71.

16. See the Rosh Hashanah 1939 sermon by Abraham H. Feinberg of Illinois, in Jewish Preaching in Times of War, pp. 389-398, quotations from Ferdinand Isserman of St. Louis, ibid., pp. 451-453, and Harold I. Saperstein, Witness from the Pulpit: Topical Sermons 1933-1980 (Lanham, Md.: Lexington Press, 2000), p. 69. These sermons, combining a fierce denunciation of Nazi Germany with a strong insistence that the US learn the lesson from the Great War and stay out of this new European conflict, were characteristic of US rabbis in all denominations in the autumn of 1939 and considerably later.

17. Harry Joshua Stern, "The Jewish Spirit Triumphant" (Rosh Hashanah 5700), in The Jewish Spirit Triumphant, p. 14, and cf. the stronger statement on p. 78.

18. An edition of Eisendrath, "Blackout: How Long, O Lord, How Long?" 21 September 1941, is in Saperstein, Jewish Preaching in Times of War, pp. 419-430. 